\section{UC8-1, UC10-1, and UC26-1: Three Celery Lines Resistant to Fusarium Yellows}

\author{
C.F. Quiros, V. D'Antonio, A.S. Greathead ${ }^{1}$, and R. Brendler ${ }^{2}$ \\ Department of Vegetable Crops, University of California, Davis, CA 95616
}

Additional index words. Apium graveolens, celeriac, disease resistance, vegetable breeding
The lines UC8-1, UC10-1, and UC26-1 were developed by the celery breeding program at the Univ. of California, Davis (supported by the California Celery Research Advisory Board). The main constraint to celery [Apium graveolens L. f. dulce (Mill.) Pers.] production in California is the widespread occurrence of fusarium yellows (caused by Fusarium oxysporum f.s. apii, race 2) in the fields. This pathogen is present in production areas in Michigan, Wisconsin, and Ohio, and in British Columbia, Canada. The lack of chemical control for this disease precludes cultivating celery in infested land. Thus, the only alternative is to develop fusarium-resistant cultivars. That option was feasible because of the high level of resistance observed in celeriac [A. graveolens f. rapaceum (Mill.) Gandich.], another cultivated form of $\boldsymbol{A}$. graveolens (Orton et al., 1984). Furthermore, the resistance is partially dominant and is probably determined by two genes. However, a single dominant allele, for gene $F u l$, from celeriac is sufficient to confer an adequate level of resistance under most conditions (Quiros, 1991). Thus, by backcrossing resistant celeriac to celery, followed by selection, the $F u l$ gene was transferred into celery. In 1984, we released the resistant line UC1 (Orton et al., 1984), which served as the source of the more advanced lines UC8-1, UC10-1, and UC26-1.

\section{Origin and disease reaction}

The three lines are derived from individual plants selected from UC1 for resistance to fusarium and improved horticultural traits. Typical plants of each line are depicted in Fig. 1 and on the front cover of this issue.

UC8-1 originated from a single-plant selection of UC1 (84A8-1) crossed once to the cultivar T.U.52-70R Improved, followed by two cycles of selfmg $\left(\mathrm{F}_{3}\right)$. A single resistant $\mathrm{F}_{2}$

Received forpublication 24 Feb. 1992. Accepted for publication 20 July 1992. The cost of publishing this paper was defrayed in part by the payment of page charges. Under postal regulations, this paper therefore must be hereby marked advertisement solely to indicate this fact.

'Cooperative Extension, Monterey County, Univ. of California, Salinas (retired).

${ }^{2}$ Cooperative Extension, Ventura County, Univ. of California, Ventura (retired). plant was selfed to generate the $\mathrm{F}_{3}$. Eleven selected resistant $\mathrm{F}_{3}$ plants were intercrossed to produce the release UC8-1. That line was heterogeneous for resistance and horticultural traits. Three independent tests on fusariuminfested fields in three California locations indicated that $74 \%$ of the plants in that line were resistant. UC8-1 will be useful to perform single-plant selections for resistance and horticultural traits.
UC10-1 was derived from UC1 plant 84A10-1 crossed once to 'T.U.52-70R Improved', followed by two cycles of selfing $\left(F_{3}\right)$. A single resistant $F_{2}$ plant was selfed to generate the $\mathrm{F}_{3}$ progeny. Ten selected $\mathrm{F}_{3}$ plants were intercrossed to produce UC10-1. That line was also heterogeneous for resistance and horticultural traits. However, four independent tests at four fusarium-infested locations indicated that UC10-1 was more uniform than UC8-1. On average, $92 \%$ of the plants in that line were resistant to the disease. The plants were dark green and compact and had very few suckers. Individuals from UC10-1 could be further improved for type by crossing to other cultivars.

UC26-1 originated from UC1 plant 84A161-26 crossed once to 'T.U.52-70HK', followed by one generation of selfing $\left(\mathrm{F}_{2}\right)$. Four selected resistant $\mathrm{F}_{2}$ plants were intercrossed to produce UC26-1. On average, 76\% of the plants in that line were resistant to the disease. Four independent tests of fusariuminfested locations indicated that UC26-1 was the most heterogeneous of all three lines. It

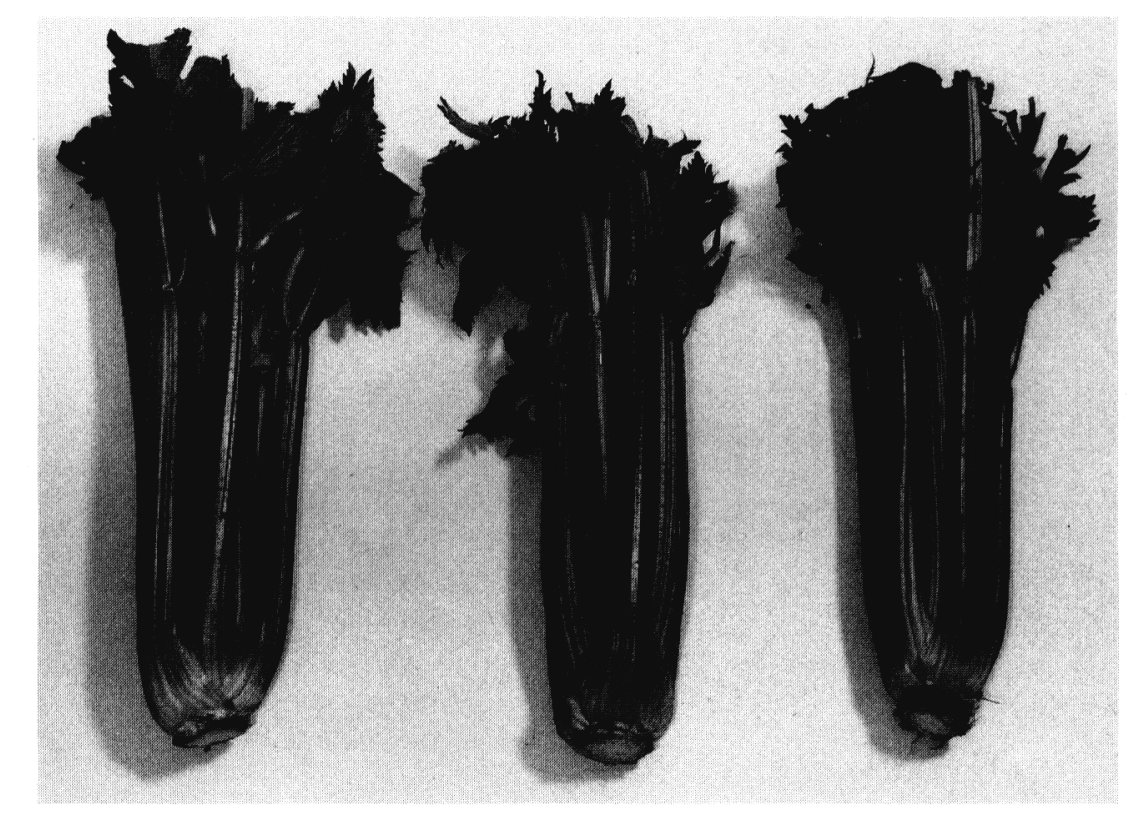

Fig. 1. Trimmed plants of (from left to right) lines UC26-1, UC10-1, and UC8-1.

Table 1. Performance of fusarium-resistant lines and moderately susceptible control 'T.U.52-70HK' tested near Ventura and Salinas, Calif., in 1990. Average values from two trials unless otherwise specified.

\begin{tabular}{|c|c|c|c|c|c|c|c|c|}
\hline \multirow[b]{2}{*}{ Line } & \multicolumn{2}{|c|}{ Fusarium-infested land } & \multicolumn{6}{|c|}{ Fusarium-free land } \\
\hline & $\begin{array}{c}\text { Disease } \\
\text { rating }^{\mathrm{t}}\end{array}$ & $\begin{array}{l}\mathrm{Wt}^{\mathrm{z}} \\
(\mathrm{g})\end{array}$ & $\begin{array}{l}\mathrm{Wt}^{\mathrm{z}} \\
(\mathrm{g})\end{array}$ & $\begin{array}{c}\text { Seeders }^{y} \\
(\%)\end{array}$ & $\begin{array}{c}\operatorname{Rib}^{\mathbf{x}} \\
\text { rating }\end{array}$ & $\begin{array}{l}\text { Pithw } \\
\text { rating }\end{array}$ & $\begin{array}{l}\text { Color }{ }^{v} \\
\text { rating }\end{array}$ & $\begin{array}{r}\text { Sucker } \\
\text { rating }\end{array}$ \\
\hline$\overline{\mathrm{UC} 8-1}$ & $1.8 \mathrm{a}$ & $856 a$ & $824 a$ & 3 & $2.7 \mathrm{a}$ & $1.8 \mathrm{a}$ & $3.2 \mathrm{a}$ & $4.2 \mathrm{a}$ \\
\hline UC10-1 & $1.4 \mathrm{a}$ & 917 a & $844 a$ & 25 & $3.3 \mathrm{c}$ & $1.0 \mathrm{a}$ & $3.5 \mathrm{a}$ & $3.2 \mathrm{c}$ \\
\hline UC26-1 & $1.8 \mathrm{a}$ & 857 a & $765 \mathrm{a}$ & 25 & $3.0 \mathrm{~b}$ & $1.2 \mathrm{a}$ & $5.0 \mathrm{~b}$ & $4.0 \mathrm{ab}$ \\
\hline $52-70 \mathrm{HK}$ & $2.9 \mathrm{~b}$ & $672 \mathrm{~b}$ & $864 \mathrm{a}$ & 11 & $3.2 \mathrm{c}$ & $1.1 \mathrm{a}$ & $4.5 \mathrm{~b}$ & $3.5 \mathrm{bc}$ \\
\hline
\end{tabular}

'Disease rating: 1 = fusarium free, $5=$ dead.

${ }^{z} \mathrm{Wt}$ : fresh weight, untrimmed plants.

ySeeders: Evidence of seedstalk after cutting plant longitudinally, based on single trial in Ventura.

"Ribbiness rating: 1 = no ribs, 5 = extreme ribbiness, based on single trial in Salinas.

"Pithiness rating: 1 = no pithiness, 5 = severe pithiness, based on single trial in Salinas.

'Color rating: $1=$ dark green, 5 = lightest green, based on single trial in Salinas.

"Suckering rating: 1 = sucker free, 5 = heavy suckering, based on single trial in Salinas. Mean separation within columns, $P<0.05$. 
will be useful for resistance and horticultural type individual plant selections.

\section{Performance}

The three lines were. tested extensively in replicated trials in California fields with and without the disease. Their performance was fairly consistent across experiments in fusarium-infested and fusarium-free plots (Table 1). In general, the lines had a high level of fusarium resistance not observed in any other commercial cultivars. Lines UC10-1 and UC26-1 tended to have more fast bolters than normal.
Line UC8-1 was preferred by most growers because of its uniformity and dark-green appearance. The resistance of those lines was confirmed in trials carried out in fusariuminfested fields in Michigan (M. Lacy, personal communication) and British Columbia (Wahlgren and Odermatt, 1990).

\section{Availability}

The three lines are being released as public enhanced germplasm without restrictions. Onegram seed samples can be obtained by sending a written request to C.F.Q.

\section{Literature Cited}

Orton, T.J., S.H. Hulbert, M.E. Durgan, and C.F. Quiros. 1984. UC1, fusarium yellows-resistant celery breeding line. HortScience 19:594.

Quiros, C.F. 1991. Celery breeding and genetics, p. 523-534. In: N. Kalloo and B.O. Bergh (eds.). Genetic improvement of vegetable crops. Pergamon Press, Oxford, U.K.

Wahlgren, S. and W. Odermatt. 1990. Selection of celery cultivars suitable for the Cloverdale area. DATE Project N. 297. British Columbia Ministry of Agriculture and Fisheries, Canada. 